\title{
The Mediation Effect of Innovative Behavior on the Relationship Between Entrepreneurial Self-Efficacy and Entrepreneurial Intention
}

Submitted 18/06/20, $1^{\text {st }}$ revision $24 / 07 / 20,2^{\text {nd }}$ revision $18 / 08 / 20$, accepted $15 / 09 / 20$

\author{
Diego Noreña-Chavez ${ }^{1}$
}

\begin{abstract}
:
Purpose: This paper analyzes the mediating effect of innovative behavior on the relationship between entrepreneurial self-efficacy and entrepreneurial intention.

Design/Methodology/Approach: Partial least squares structural equation modeling (PLSSEM) was used in a sample of 358 owners in medium and big companies in a textile cluster in Peru.

Findings: Results show that there is a significant complementary mediation effect of innovative behavior between entrepreneurial self-efficacy and entrepreneurial intention.

Practical Implications: This finding is important in order to further advance the understanding of the direct and indirect causes of entrepreneurial intention.

Originality/Value: Finally, this is especially important for understanding entrepreneurial intention in an extractive emerging economy.
\end{abstract}

Keywords: Entrepreneurial intention, entrepreneurial self-efficacy, innovative behavior, mediation model.

JEL codes: $M 21$.

Paper type: Research article.

\footnotetext{
${ }^{1}$ PSB-Paris School of Business, 59 rue Nationale, Paris Ile-de-France, France Affiliation ID: 60158043.ORCID: 0000-0001-5292-2152.email: diego.norena@hotmail.com;
} 


\section{Introduction}

Entrepreneurship has received greater attention due to the socio-economic development in emerging countries (Zemtsov, 2020; Shan, Jia, Zheng, and Xu, 2018; Kreitmeyr, 2017). It is known that there are personal and environmental factors that motivate people to start ventures (Marques, Valente, and Lages, 2018; Wang, Hung, and Huang, 2019). Researchers have primarily applied the theory of planned behavior (Ajzen, 1991) to explain people's behavior based on cognitive processes' assumptions and predict business intention.

One of the principal explanations for why people seek to undertake is entrepreneurial self-efficacy or belief in a personal capacity (Chen et al., 1998). Research suggests that people who believe they can be entrepreneurial will intend to do so (Ajzen, 1991). Specifying the factors that predict entrepreneurial intention is crucial on several social fronts: academics, the university community, the government, and civil society to improve the intention to choose entrepreneurship (Wickam, Finley, and Saeger, 2020; Kaijun and Sholihah, 2015). The literature suggests self-efficacy as the strongest personal factor influencing entrepreneurial intention (Newman et al., 2018; Noreña-Chávez and Guevara, 2020). However, little is known about the mechanism through which entrepreneurial self-efficacy affects entrepreneurial intention, and the relationship is mediated by innovative behavior.

Therefore, this study aims to know the mediating effect of innovative behavior on the relationship between entrepreneurial self-efficacy and entrepreneurial intention. The findings provide one of the first empirical studies that explore the mediating links between self-efficacy and entrepreneurial intention in an emerging economy.

The study took Noreña-Chávez and Guevara (2020) as its starting point, using February 2020 data from entrepreneurs in 358 medium and large companies located in the Gamarra commercial emporium in Peru. A review of the main theories, the theoretical model, the research method, the results, discussion, and conclusions are detailed.

\section{Theoretical background}

\subsection{Entrepreneurial Self-Efficacy}

To understand the origin of entrepreneurial self-efficacy, it is necessary to realize that its roots lie in Bandura's social cognitive theory (1986). This theory is based on the following variables: a) behavioral influences, b) personal influences, and c) environmental influences. Important to social cognitive theory is that human functioning is influenced by people's judgments about their abilities to organize and execute the courses of action required to achieve the designated types of performance (Bandura, 1986). 
According to Bandura (1997), self-efficacy is a domain-specific variable directed at a given behavior to complete any task. Bandura (1986) concluded that people's beliefs about their effectiveness could be supported and strengthened in several ways; however, the most effective way for individuals to develop a strong sense of effectiveness is through mastery experiences.

Self-efficacy and other specific ways of mastery, such as entrepreneurial selfefficacy, have theoretical roots in perspective, evaluating individuals' interaction reciprocally with internal and external environments (Bandura, 1997). The Entrepreneurial Self-Efficacy is a variant of self-efficacy and is based on the following variables: a) observation, b) social context, and c) behavior in social learning (Bandura, 2006). According to Newman, Obschonka, Schwarz, Cohen, and Nielsen (2018), entrepreneurial self-efficacy has the following background: a) work experience, b) education and training, c) presence of mentors, d) individual differences, e) company characteristics and f) cultural and institutional environment.

\subsection{Entrepreneurial Intention}

According to Krueger et al. (2000), a person may consider becoming an entrepreneur consciously and voluntarily. Lee and Wong (2004) concluded that entrepreneurial intention is the initial process of entrepreneurship since companies' creation arises from this variable. Fishbein and Ajzen (1975) stated that entrepreneurial intention comes from the psychology field, mainly from the social cognitive theory. These researchers defined intention as the variable intercepting the constructs of behavior and belief. Azjen (1991) concluded that three variables precede entrepreneurial intention. First, the personal attitude, which consists of the evaluation that an individual has about entrepreneurship's viability. Second, the subjective norms, which are the perceptions that society has about the decision to undertake. Finally, control of perceived behavior, which is the perceived difficulty of becoming an entrepreneur. According to Krueger and Carsrud (1993), entrepreneurial intention is the individual decision that some people have to start a new business. Entrepreneurial intention is a crucial variable for entrepreneurship since it positively influences the opening of new companies.

Thompson (2009) investigated the influence of entrepreneurial intention as regards the creation of new businesses. His study concluded the high correlation of this variable in different contexts and the development of a scale applicable to international contexts of new business generation. The entrepreneurial intention mediates the learning process, the entrepreneurial experience, and the risk of starting a new business (Zhao, Seibert, and Hills, 2005). This research followed a quantitative methodological approach using PLS-SEM in a sample of 265 university students of a master's program.

On the other hand, Hmieleski and Corbett (2006) concluded that entrepreneurial intention is positively correlated with improvisation. They studied entrepreneurial 
intention and its influence on motivation, cognitive styles, and social models in a sample of 430 students. Entrepreneurial intention and entrepreneurial education are positively related (Fayolle and Gailly, 2013; Pittaway and Cope, 2007).

In both investigations, it was concluded that the greater the exposure of students to entrepreneurship-related subjects, the greater the entrepreneurial intention of the students. In Kristiansen and Indarti's (2004) study on entrepreneurial intention among young students in Indonesia and Norway, the following variables were compared: a) attitudes, b) demographic factors, and c) personal background. It was concluded that entrepreneurial intention is high among students in both countries, and the variable that most influences both samples are the salary of the people who undertake.

\subsection{Innovative Behavior}

Innovation in organizations depends on people's behavior (Thurlings, Evers, and Vermeulen, 2015). Scott and Bruce (1994) defined innovative behavior as the process of value creation supported by the generation of new ideas, solutions, and applications. Innovative behavior begins with creativity but is differentiated by execution (Amabile, 1988). Konermann (2012) defined innovative behavior as a process that integrates the following variables: a) generation, b) development, c) application, d) execution, and e) modification of new ideas to increase the performance of an organization.

Innovative behavior is the adoption of innovative processes and ideas to increase organizational performance, impacting sustainability (Janssen, 2000). Innovative behavior is a variant of performance different from others since it exceeds the established requirements by adding innovative variables (Aryee, Walumbwa, Zhou, and Hartnell, 2012). Newman et al. (2018) defined innovative behavior as a competence valued and expected by many people, given its high organizational performance impact. The benefits of innovative behavior outweigh the economic ones and influence psychological ones, since they increase social changes, improve employees' self-esteem, and generate social changes (Rank, Pace, and Frese, 2004).

Innovative behavior is a crucial variable for organizational success in many fields. The academics must incorporate it in education since teachers must influence their students in innovative ways (Thurlings, Evers, and Vermeulen, 2015). From the financial point of view, organizations with employees with innovative behavior skills increase their profitability and accelerate organizational success (Heunks, 1998).

\subsection{The Model}

This research was adapted from the model presented by (Noreña-Chavez and Guevara, 2020) and showed the following variables: a) entrepreneurial self-efficacy 
as an independent variable; b) innovative behavior as a mediating variable; and c) entrepreneurial intention as a dependent variable. This research will determine the mediation effect of innovative behavior on the relationship between entrepreneurial self-efficacy and entrepreneurial intention. This research proposes the following hypotheses:

H1: Innovative behavior has a mediating effect on the relationship between entrepreneurial self-efficacy and entrepreneurial intention.

H2: Entrepreneurial self-efficacy and innovative behavior are positively related.

H3: Entrepreneurial self-efficacy and entrepreneurial intention are positively related.

H4: Innovative behavior and entrepreneurial intention are positively related.

Figure 1 shows the model proposed in this research and the hypotheses to be proven.

Figure 1. The model explains the mediation of innovative behavior in the relationship between entrepreneurial self-efficacy and entrepreneurial intention.

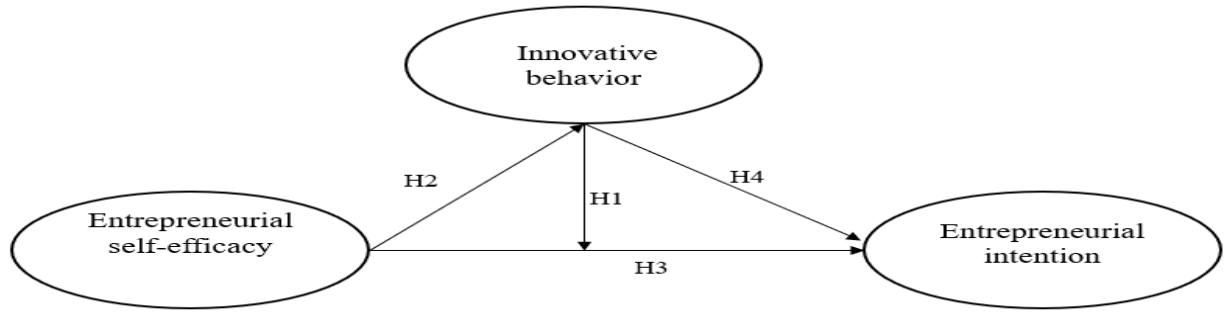

Source: Adapted from "Entrepreneurial Passion and Self-Efficacy as Factors Explaining Innovative Behavior: A Mediation Model” (Noreña-Chavez and Guevara, 2020)

\section{Methodology and Data}

This research followed a quantitative methodological approach with an explanatorycorrelational scope, a cross-sectional cohort, and a non-experimental design. The partial least squares structural equation modeling (PLS-SEM) was used due to the research's nature since there are non-observable variables that will be measured by indicators and research background. In this field, the same multivariate statistical technique of the second generation was used (Chin, 1998; Henseler, Ringle, and Sinkovics, 2009; Hair, Ringle, and Sarstedt, 2011; Hair et al., 2014; Sarstedt et al., 2014). The hypothesis of the mediating role is supported by previous studies by (Mathieson, Peacock and Chin, 2001; Henseler, 2010; Gelbrich, 2010; Henseler and Chin 2010; Preacher and Hayes, 2008; LeBreton, Wu, and Bing, 2009; Williams and MacKinnon, 2008; MacKinnon, Lockwood, and Williams 2004; Sun, 2010).

Three scales were used in this research: a) entrepreneurial self-efficacy scale (De Noble, Jung and Ehrlich, 1999), b) entrepreneurial intention scale (Ajzen, 2006), and c) innovative behavior scale (Janssen, 2000). The following criteria were used to 
evaluate the measurement model: a) individual factorial load, b) internal consistency measured through the Alpha coefficient and composite reliability, c) convergent validity through the AVE, d) discriminant validity through the Fornell and Larcker index and the HTMT. The following criteria were used to evaluate the structural model: (a) goodness-of-fit index, (b) evaluation of the statistical significance of the hypotheses, (c) total indirect effect and its statistical significance, (d) total direct effect and its statistical significance, (e) the explanatory effect of the structural model, and (f) the predictive effect of the structural model.

Table 1 shows the number and size of companies located in the Gamarra Commercial Emporium according to the Economic Development Unit of the Municipality of La Victoria in a pre-COVID-19 context.

Table 1. Classification of the companies located in the GTC by industry

\begin{tabular}{lll}
\hline Industry & Number of Companies & $\begin{array}{l}\text { Small, Medium and } \\
\text { Large Companies }\end{array}$ \\
\hline Clothing sale & 45,423 & 36,000 \\
Others & 18,995 & 7,439 \\
Total & 64,418 & 43,439 \\
\hline
\end{tabular}

Source: Data provided by the Economic Development Unit of the Municipalidad de La Victoria in February 2020.

\section{Empirical Results}

\subsection{Evaluation of the Measurement Model}

The individual factorial load was the first criterion evaluated and indicators with a load less than 0.707 were eliminated (Carmines and Zeller, 1979). Table 2 shows entrepreneurial self-efficacy, innovative behavior and entrepreneurial intention with its indicators and loads.

Table 2. Measurement model assessment results

\begin{tabular}{|c|c|c|}
\hline Variables & Indicators & Loads \\
\hline \multirow{11}{*}{ Entrepreneurial Self-Efficacy } & Inspire others to accept the vision and values & 0.76 \\
\hline & Create products that meet customer needs & 0.72 \\
\hline & Formulate quick actions to pursue opportunities & 0.74 \\
\hline & Develop an innovative work environment & 0.73 \\
\hline & Determine business performance & 0.72 \\
\hline & Motivate people to have initiative & 0.73 \\
\hline & Build management teams & 0.72 \\
\hline & Establish the vision of the organization & 0.71 \\
\hline & Innovate existing products & 0.74 \\
\hline & Identify areas of potential growth & 0.74 \\
\hline & Develop robust planning & 0.73 \\
\hline
\end{tabular}


Innovative Behavior

Entrepreneurial Intention

$\begin{array}{ll}\text { Look for new methods and techniques } & 0.80 \\ \text { Transform innovative ideas into useful } & 0.83 \\ \text { applications } & 0.80 \\ \text { Introduce innovative ideas systematically } & \\ \text { Motivate the members of the organization to } & 0.81 \\ \text { innovate } & 0.82 \\ \text { Generate original solutions } & 0.87 \\ \text { Create new ideas } & 0.77 \\ \text { Mobilize support for new ideas } & 0.84 \\ \text { Evaluate the application of new ideas } & 0.89 \\ \text { I plan to create a company } & 0.93 \\ \text { I will strive to be an entrepreneur } & 0.92 \\ \text { I am determined to be an entrepreneur } & \end{array}$

Source: Based on 358 surveys. Own elaboration.

The psychometric properties of the instruments were the second criterion evaluated. The internal consistency measured through the alpha coefficient showed values between 0.91 and 0.93 . The internal consistency measured through the composite reliability showed values between 0.93 and 0.94 . Internal consistency was also tested for robustness (Chin, 1998; Nunnally and Bernstein, 1994). Convergent validity measured through AVE showed values between 0.53 and 0.84 . Convergent validity was robust since it is greater than 0.5 (Chin, 1998). Table 3 shows the internal consistency measured through alpha, composite reliability, and Ave.

Table 3. Validity and reliability

\begin{tabular}{llll}
\hline & Alpha & Composite reliability & AVE \\
\hline Entrepreneurial Intention & .90 & .94 & .84 \\
Entrepreneurial Self-Efficacy & .91 & .93 & .53 \\
Innovative Behavior & .93 & .94 & .67 \\
\hline
\end{tabular}

Source: Based on 358 surveys. Own elaboration.

As a third criterion, discriminant validity was evaluated as measured by the Fornell and Larcker, and the HTMT indexes. Table 4 shows that the correlations between the variables are less than the AVE's square root in all cases, and the evaluation criterion of (Fornell and Larcker, 1981) was met.

Table 4. Fornell-Larcker criterion to analyze discriminant validity

\begin{tabular}{|c|c|c|c|}
\hline & $\begin{array}{l}\text { Entrepreneurial } \\
\text { Intention }\end{array}$ & $\begin{array}{l}\text { Entrepreneurial Self- } \\
\text { Efficacy }\end{array}$ & $\begin{array}{l}\text { Innovative } \\
\text { Behavior }\end{array}$ \\
\hline Entrepreneurial Intention & .914 & & \\
\hline $\begin{array}{l}\text { Entrepreneurial } \\
\text { Efficacy }\end{array}$ & .226 & .730 & \\
\hline Innovative Behavior & .280 & .458 & .817 \\
\hline
\end{tabular}

Source: Based on 358 surveys. Own elaboration. 
Table 5 shows that the HTMT index is less than 0.85 , requiring discriminant validity (Hair, Hult, Ringle, Sarstedt Thiele, 2017).

Table 5. HTMT criterion to analyze discriminant validity

\begin{tabular}{llll}
\hline & $\begin{array}{l}\text { Entrepreneurial } \\
\text { Intention }\end{array}$ & $\begin{array}{l}\text { Entrepreneurial } \\
\text { Self-Efficacy }\end{array}$ & $\begin{array}{l}\text { Innovative } \\
\text { Behavior }\end{array}$ \\
\hline $\begin{array}{l}\text { Entrepreneurial Intention } \\
\text { Entrepreneurial Self- }\end{array}$ & & & \\
Efficacy & .248 & & \\
Innovative Behavior & .301 & .490 & \\
\hline
\end{tabular}

Source: Based on 358 surveys. Own elaboration.

\subsection{Evaluation of the Structural Model}

The analysis of the structural model showed goodness-of-fit indexes with a $9 \%$ variance explained. Figure 2 presents the assessment of the structural model. It shows reflective constructs and their factor loadings, as well as the routes proposed in the hypotheses.

Figure 2. Conceptual model of the factors that explain the mediation effect of innovative behavior on the relationship between entrepreneurial self-efficacy and entrepreneurial intention

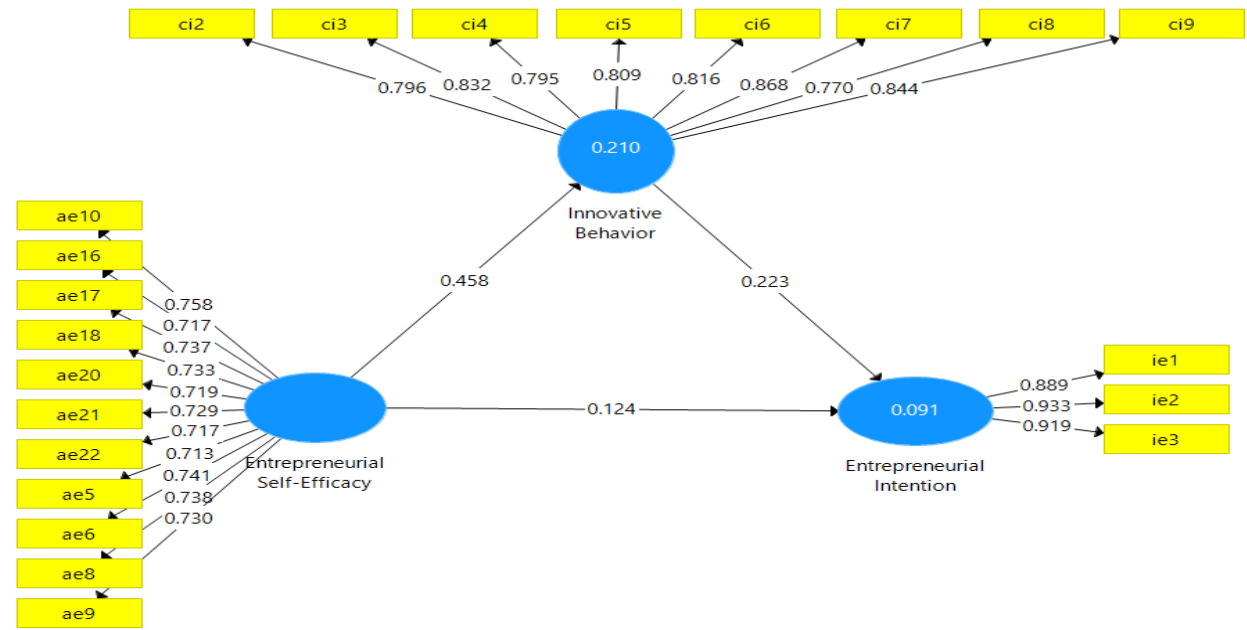

Note: Created with SmartPLS 3. Algorithm for missing values = Case wise replacement . Weighted scheme for routes.

Source: Based on 358 surveys. Own elaboration.

Regarding hypothesis 2, the significant effect was verified on the effect of entrepreneurial self-efficacy on entrepreneurial intention, $\beta=0.124, p=0.007$. Regarding hypothesis 3 , the significant effect was confirmed on entrepreneurial selfefficacy on innovative behavior, $\beta=0.458, p=0.000$. For hypothesis 4 , on the effect 
of innovative behavior on entrepreneurial intention, the significant effect was verified, $\beta=0.223, p=0.000$. Table 6 shows a summary of the direct relationships and their statistical significance.

Table 6. Path coefficients and bootstrapping results

\begin{tabular}{lll}
\hline Causal routes & Route coefficients & $p$ \\
\hline ESE -> EI & .124 & .007 \\
ESE ->IB & .458 & .000 \\
IB $>$ EI & .223 & .000 \\
\hline
\end{tabular}

Note: Obtained with SmartPLS3. Algorithm for missing values = Case wise

Source: Created by the authors using the results of the study. $S D=$ Standard deviation.

For the evaluation of hypothesis 1 on the mediating effect of innovative behavior on the relationship between entrepreneurial self-efficacy and entrepreneurial intention, bootstrapping of 5000 iterations was used. The results are shown in Table 7, the mediation is positive and significant.

Table 7. Total indirect effects of the structural components

\begin{tabular}{lcc}
\hline Causal routes & Sample mean & SD \\
\hline ESE $->$ EI & 0.102 & 0.029 \\
\hline
\end{tabular}

Note: Obtained with SmartPLS 3

Source: Created by the author using the results of the study

For determining the type of mediation in the model, the total direct effects were evaluated and concluded to be positive and significant. After assessing the total direct and indirect effect, the complementary mediating effect of innovative behavior on entrepreneurial self-efficacy and the entrepreneurial intention was proven. The explanatory power of the structural model was evaluated using R2 and F2. The model presented an R2 of 0.091 and an F2 of 0.013 . Therefore the explanatory power is low. Q2 and q2 evaluated the predictive power of the structural model. The model presented a Q2 of 0.072 and a q2 of 0.031 , so the predictive power is low.

\section{Discussion}

This research's objective was to determine the mediating effect of innovative behavior on the relationship between entrepreneurial self-efficacy and entrepreneurial intention, based on the model proposed by (Noreña-Chavez and Guevara, 2020). The direct and indirect relationships of the variables presented in this model were proven (Entrepreneurial Self-Efficacy, Innovative Behavior, and Entrepreneurial Intention).

The H1 is statistically significant, so it was accepted. Due to this study's exploratory nature, no extensive empirical evidence has been found to support this hypothesis. 
However, some studies have measured the variables proposed in this study in similar relationships. For example, Lee et al. (2019) found that entrepreneurship mediates innovative intention and behavior. The researchers found that greater intention leads to more innovative behavior and that entrepreneurship serves as an essential link in this relationship. These results differ from the findings of this study because of the different causal pathways. On the other hand, Pihie and Bagheri (2013) analyzed the mediating effect of self-regulation on the relationship between self-efficacy and entrepreneurial intention. The findings revealed that a sample of students' entrepreneurial self-efficacy had a significant positive impact on their intention to become entrepreneurs. That is, this evidence supports the hypotheses raised in this study.

This hypothesis was found to be statistically significant regarding $\mathrm{H} 2$ (the relationship between entrepreneurial self-efficacy and innovative behavior). Research such as that of (Noreña-Chavez and Guevara, 2020, Newman et al., 2018; Schjoedt and Craig 2017; Spagnoli et al., 2017) supports the results of this relationship. On the other hand, Chen and Zhou (2017) concluded that entrepreneurial self-efficacy and innovative behavior are negatively related.

About H3 (the relationship between entrepreneurial self-efficacy and entrepreneurial intention), the hypothesis is statistically significant. Likewise, it was found that entrepreneurial self-efficacy has a positive influence on entrepreneurial intention. The results found in this research are supported by the following previous research (Boyd and Vozikis, 1994; Zhao, Seibert, and Hills, 2005; Cardon and Kirk, 2015; Bullough, Renko, and Myatt, 2013; Hsu et al., 2018; Tsai, Chang, and Peng, 2014).

Concerning H4 (the relationship between innovative behavior and entrepreneurial intention), previous research has shown that entrepreneurial intention can be influenced and guided by both personal and environmental factors (Souitaris et al., 2007). There is evidence that supports the hypothesis of the relationship between the variables of innovative behavior and entrepreneurial intention. The study by Lee et al. (2019) raised whether greater intention led to innovative behavior. Although the relationship is inverse to that of this study, the authors found that the intention to implement affected innovative behavior. On the other hand, Kim et al. (2018) found that innovative behavior is an essential variable in problem-solving. That is, the authors demonstrated that a person's problem-solving ability is affected by innovative behavior. Precisely, in the business field, problem-solving is an appreciated variable.

\section{Conclusion}

Self-efficacy is the strongest predictor of entrepreneurial intent. Some variables mediate the relationship between both variables, and academics and the business world must understand entrepreneurship better. This study is one of the first empirical supports of self-efficacy, entrepreneurial intention, and innovative 
behavior. Therefore, the proposed exploratory model can be tested in different populations and used by researchers in entrepreneurship.

The model also provides a better understanding of the mechanism through which entrepreneurial self-efficacy affects entrepreneurial intention. However, only the innovative behavior was raised as the factor regulating the relationship between both variables. Future research could invest efforts in examining other hypotheses involving personal, social, cultural, etc.

The research sought to propose a model that could explain entrepreneurial behavior in a particular context before the pandemic caused by COVID-19. Therefore, the new social, political, and business context requires a re-evaluation of post-pandemic outcomes. Likewise, due to the changes and little evidence in this field, given the new business context, it is suggested to include other mediating variables such as age, sex, education, and technology exposure. This would guarantee the structure of the routes between entrepreneurial self-efficacy, entrepreneurial intention, and innovative behavior. Finally, including a different design to the cross-sectional one could provide us with significant findings, that is, longitudinal studies.

\section{References:}

Amabile, T.M. 1988. A model of creativity and innovation in organizations. Research in organizational behavior, 10(1), 123-167.

Ajzen, I. 1991. The theory of planned behavior. Organizational Behavior and Human Decision Processes, 50(2) 1-63.

Ajzen, I. 2006. Constructing a theory of planned behavior questionnaire.

Aryee, S., Walumbwa, F.O., Zhou, Q., Hartnell, C.A. 2012. Transformational Leadership, Innovative Behavior, and Task Performance: Test of Mediation and Moderation Processes. Human Performance, 25(1), 1-25. doi:10.1080/08959285.2011.631648.

Bandura, A. 1986. Social foundations of thought and action: A social cognitive theory. Englewood Cliffs, NJ, Prentice-Hall.

Bandura, A. 1997. Self-efficacy: The exercise of control. New York, Freeman.

Bandura, A. 2006. Guide for constructing self-efficacy scales. In: Pajares, F., Urdan, T. (Eds.), Self-efficacy Beliefs of Adolescents. Information Age Publishing, Greenwich, CT, 307-337.

Barakat, S., Boddington, M., Vyakarnam, S. 2014. Measuring entrepreneurial self-efficacy to understand the impact of creative activities for learning innovation. The International Journal of Management Education, 12, 456-468. https://doi.org/10.1016/j.ijme.2014.05.007.

Barbosa, S., Gerhardt, M., Kickul, J. 2007. The role of cognitive style and risk preference on entrepreneurial self-efficacy and entrepreneurial intentions. Journal of Leadership and Organizational Studies, 13, 86-104. https://doi.org/10.1.1.472.1835.

Boyd, N.G., Vozikis, S.G. 1994. The Influence of Self-Efficacy on the Development of Entreprenurial Intentions and Actions. Entrepreneurship Theory and Practice, 63-77

Bullough, A., Renko, M., Myatt, T. 2013. Danger Zone Entrepreneurs: The Importance of Resilience and Self-Efficacy for Entrepreneurial Intentions. Entrepreneurship Theory and Practice, 38(3), 473-499. https://doi.org/ 10.1111/etap.12006. 
Cardon, S.M., Kirk, C.P. 2015. Entrepreneurial Passion as Mediator of the Self-Efficacy to Persistence Relationship. Entrepreneurship Theory and Practice, 39(5). 1027-1050.

Carmines, E.G., Zeller, R.A.1979. Reliability and validity assessment. N. 07-017, Sage University Paper Series on Quantitative Applications in the Social Sciences. Beverlly Hills, CA: Sage.

Chen, C.C., Greene, P.G., Crick, A. 1998. Does entrepreneurial self-efficacy distinguish entrepreneurs from managers? Journal of Business Venturing, 13(4), 295-316. https://doi.org/10.1016/s0883-9026(97)00029-3.

Chen, Y., Zhou, X. 2017. Entrepreneurial self-efficacy and firms' innovation behavior: The negative mediating role of social capital. Social Behavior and Personality: an international journal, 45(9), 1553-1562. https://doi.org/10.2224/sbp.6734.

Chin, W.W. 1998. Commentary: Issues and opinion on structural equation modeling. https://www.jstor.org/stable/249674

Cronbach, L.J. 1951. Coefficient alpha and the internal structure of tests. Psychometrika, 16(3), 297-334.

De Noble, A.F., Jung, D., Ehrlich, B. 1999. Entrepreneurial self-efficacy: the development of a measure and its relationship to entrepreneurial intentions and actions. Entrepreneurship Theory and Practice, 18(4), 63-77.

Fayolle, A., Gailly, B. 2013. The Impact of Entrepreneurship Education on Entrepreneurial Attitudes and Intention: Hysteresis and Persistence. Journal of Small Business Management, 53(1), 75-93. https://doi.org/ 10.1111/jsbm.12065.

Fishbein, M., Ajzen, I. 1975. Belief, attitude, intention and behavior: An introduction to theory and research. Reading, Mass., Addison-Wesley.

Fornell, C., Larcker, D. 1981. Evaluating structural equation models with unobservable variables and measurement error. Journal of Marketing Research, 18, 39-50.

Gelbrich, K. 2010. Anger, frustration, and helplessness after service failure: coping strategies and effective informational support. Journal of the Academy of Marketing Science, 38(5), 567-585. https://doi.org/10.1007/s11747-009-0169-6.

Hair, J.F., Ringle, C.M., Sarstedt, M. 2011. PLS-SEM: Indeed, a silver bullet. Journal of Marketing theory and Practice, 19(2), 139-152.

Hair Jr, J.F., Sarstedt, M., Hopkins, L., Kuppelwieser, V.G. 2014. Partial least squares structural equation modeling (PLS-SEM). European business review. https://doi.org/10.1108/EBR-10-2013-0128.

Hair, J.F., Hult, G.T.M., Ringle, C.M., Sarstedt, M., Thiele, K.O. 2017. Mirror, mirror on the wall: a comparative evaluation of composite-based structural equation modeling methods. Journal of the Academy of Marketing Science, 45(5). https://doi.org/10.1007/s11747-017-0517-x.

Henseler, J. 2010. On the convergence of the partial least squares path modeling algorithm. Computational statistics, 25(1), 107-120. https://doi.org/10.1007/s00180009-0164-x.

Henseler, J., Chin, W.W. 2010. A Comparison of Approaches for the Analysis of Interaction Effects Between Latent Variables Using Partial Least Squares Path Modeling. Structural Equation Modeling: A Multidisciplinary Journal, 17(1), 82109. https://doi.org/ 10.1080/10705510903439003.

Henseler, J., Ringle, C.M., Sinkovics, R.R. 2009. The use de partial least squares path modeling in international marketing. Advances in International marketing, 20, 277 320.

Heunks, F.J. 1998. Small Business Economics, 10(3), 263-272. https://doi.org/ 10.1023/a:1007968217565. 
Hmieleski, K.M., Corbett, A.C. 2006. Proclivity for Improvisation as a Predictor of Entrepreneurial Intentions. Journal of Small Business Management, 44(1), 4563. https://doi.org/ 10.1111/j.1540-627x.2006. 00153.x.

Hsu, D.K., Burmeister-Lamp, S.A., Simmons, M.D., Foo, M.C., Hong, M.C., Pipes, D.J. 2018. I Know I Can, But I Don't Fit': Perceived fit, Self-Efficacy, and Entrepreneurial Intention. Journal of Business Venturing, 34(2), 311-326. https://doi.org/10.1016/j.jbusvent.2018.08.004.

Janssen, O. 2000. Job demands, perceptions of effort-reward fairness and innovative work behaviour. Journal of Occupational and Organizational Psychology, 73(3), 287302. https://doi.org/ 10.1348/096317900167038.

Kaijun, Y., Sholihah, P.I. 2015. A comparative study of the Indonesia and Chinese educative systems concerning the dominant incentives to entrepreneurial spirit (desire for a new venturing) of business school students. Journal of Innovation and Entrepreneurship, 4(1), 1. https://doi.org/10.1186/s13731-014-0014-0.

Kim, J.Y., Choi, D.S., Sung, C.S., Park, J.Y. 2018. The role of problem-solving ability on innovative behavior and opportunity recognition in university students. Journal of Open Innovation: Technology, Market, and Complexity, 4(1), 4. https://10.1186/s40852-018-0085-4.

Konermann, J. 2012. Teachers' work engagement: A deeper understanding of the role of job and personal resources in relationship to work engagement, its antecedents, and its outcomes. Enschede, The Netherlands: Universiteit Twente. https://doi.org/10.3990/1.9789036533027.

Kreitmeyr, N. 2017. Entrepreneurship, crisis and socio-economic development in the Mediterranean: Formal and informal institutions and entrepreneurial activity. Mediterranean Politics, 22(3), 432-438. https://doi.org/10.1080/13629395.2016.1215045.

Kristiansen, S., Indarti, N. 2004. Entrepreneurial Intention Among Indonesian and Norwegian Students. Journal of Enterprising Culture, 12(01), 55-78. https://doi.org/ $10.1142 / \mathrm{s} 021849580400004 \mathrm{x}$.

Krueger, N.F., Carsrud, A.L. 1993. Entrepreneurial intentions: Applying the theory of planned behaviour. Entrepreneurship \& Regional Development, 5(4), 315330. https://doi.org/ 10.1080/08985629300000020.

Krueger, N.F., Reilly, M.D., Carsrud, A.L. 2000. Competing models of entrepreneurial intentions. Journal of Business Venturing, 15(5-6), 411432. https://doi.org/10.1016/s0883-9026(98)00033-0.

LeBreton, J.M., Wu, J., Bing, M.N. 2009. The truth (s) on testing for mediation in the social and organizational sciences. Statistical and methodological myths and urban legends: Doctrine, verity, and fable in the organizational and social sciences, 109144.

Lee, S.H., Wong, P.K. 2004. An exploratory study of technopreneurial intentions: a career anchor perspective. Journal of Business Venturing, 19(1), 7-28. https://doi.org/ 10.1016/s0883-9026(02)00112-x.

Lee, J., Kim, D., Sung, S. 2019. The Effect of Entrepreneurship on Start-Up Open Innovation: Innovative Behavior of University Students. Journal of Open Innovation: Technology, Market, and Complexity, 5(4), 103. https://10.3390/joitmc5040103.

MacKinnon, D.P., Lockwood, C.M., Williams, J. 2004. Confidence limits for the indirect effect: Distribution of the product and resampling methods. Multivariate behavioral research, 39(1), 99-128. https://doi.org/10.1207/s15327906mbr3901_4. 
Marques, C.S., Valente, S., Lages, M. 2018. The influence of personal and organisational factors on entrepreneurship intention: An application in the health care sector. Journal of nursing management, 26(6), 696-706. https://doi.org/10.1111/jonm.12604.

Mathieson, K., Peacock, E., Chin, W.W. 2001. Extending the technology acceptance model. ACM SIGMIS Database, 32(3), 86. https://doi.org/ 10.1145/506724.506730.

McGee, J., Peterson, M. 2017. The long-term impact of entrepreneurial self-efficacy and entrepreneurial orientation on venture performance. Journal of Small Business Management. http://dx.doi.org/10.1111/jsbm.12324.

Newman, A., Obschonka, M., Schwarz, S., Cohen, M., Nielsen, I. 2018. Entrepreneurial selfefficacy: A systematic review of the literature on its theoretical foundations, measurement, antecedents, and outcomes, and an agenda for future research. Journal of Vocational Behavior. https://doi.org/ 10.1016/j.jvb.2018.05.012.

Norena-Chavez, D., Guevara. R. 2020. Entrepreneurial Passion and Self-Efficacy as Factors Explaining Innovative Behavior: A Mediation Model. International Journal of Economics and Business Administration, VIII, Issue 3, 352-373. https://doi.org/10.35808/ijeba/522.

Nunnally, J., Bernstein, I. 1994. Psychometric theory (3a ed.). Nueva York, Estados Unidos: McGraw-Hill.

Pihie, Z.A.L., Bagheri, A. 2013. Self-efficacy and entrepreneurial intention: The mediation effect of self-regulation. Vocations and Learning, 6(3), 385-401. https://10.1007/s12186-013-9101-9.

Pittaway, L., Cope, J. 2007. Entrepreneurship Education: A Systematic Review of the Evidence. International Small Business Journal, 25(5), 479-510. https://doi.org/ $10.1177 / 0266242607080656$.

Preacher, K.J., Hayes, A.F. 2008. Asymptotic and resampling strategies for assessing and comparing indirect effects in multiple mediator models. Behavior research methods, 40(3), 879-891. https//doi.org/10.3758/BRM.40.3.879.

Rank, J., Pace, V. L., Frese, M. 2004. Three avenues for future research on creativity, innovation, and initiative. Applied Psychology: An International Review, 53(4), 518-528. https://doi.org/10.1111/j.1464-0597.2004.00185.x.

Sarstedt, M., Ringle, C.M., Hair, J.F. 2014. PLS-SEM: Looking Back and Moving Forward: Long Range Planning, 47(3), 132-137. https//: 10.1016/j.lrp.2014.02.008.

Schjoedt, L., Craig, J.B. 2017. Development and validation of a unidimensional domain specific entrepreneurial self-efficacy scale. International Journal of Entrepreneurial Behavior \& Research, 23(1), 98-113. https://doi.org/10.1108/IJEBR-11-2015-0251.

Scott, S.G., Bruce, R.A. 1994. Determinants of Innovative Behavior: A Path Model of Individual Innovation in the Workplace. Academy of Management Journal, 37(3), 580-607. https://doi.org/ 10.5465/256701.

Shan, S., Jia, Y., Zheng, X., Xu, X. 2018. Assessing relationship and contribution of China's technological entrepreneurship to socio-economic development. Technological Forecasting and Social Change, 135, 83-90. https://doi.org/10.1016/j.techfore.2017.12.022.

Souitaris, V., Zerbinati, S., Al-Laham, A. 2007. Do entrepreneurship programmes raise entrepreneurial intention of science and engineering students? The effect of learning, inspiration and resources. Journal of Business Venturing, 22, 566-591. https://doi.org/10.1016/j.jbusvent.2006.05.002.

Spagnoli, P., Santos, S., Caetano, A. 2017. A contribution toward the adaptation and 
validation of the entrepreneurial self-efficacy scale in Italy and Portugal. Journal of Career Assessment, 25(4), 670-687. https://doi.org/10.1177/1069072716664302.

Sun, H. 2010. Sellers' trust and continued use of online marketplaces. Journal of the Association for Information systems, 11(4), 2. https://doi.org/ 10.17705/1 jais.00226.

Thompson, E.R. 2009. Individual Entrepreneurial Intent: Construct Clarification and Development of an Internationally Reliable Metric. Entrepreneurship Theory and Practice, 33(3), 669-694. https://doi.org/ 10.1111/j.1540-6520.2009. 00321.x.

Thurlings, M., Evers, A.T., Vermeulen, M. 2015. Toward a Model of Explaining Teachers' Innovative Behavior. Review of Educational Research, 85(3), 430-471. https://doi.org/ 10.3102/0034654314557949.

Tsai, K., Chang, H., Peng, C. 2014. Extending the link between entrepreneurial self-efficacy and intention: a moderated mediation model. Int Entrep Manag J, 12, 445-463. https://doi.org/10.1007/s11365-014-0351-2.

Wang, S., Hung, K., Huang, W.J. 2019. Motivations for entrepreneurship in the tourism and hospitality sector: A social cognitive theory perspective. International Journal of Hospitality Management, 78, 78-88. https://doi.org/10.1016/j.ijhm.2018.11.018.

Wickam, M.J., Finley, L.R., Saeger, K. 2020. Assessing alignment of Entrepreneurial Spirit to job descriptions seeking business administration or management undergraduates. Journal of Education for Business, 95(8) 1-7. https://doi.org/10.1080/08832323.2020.1715332.

Williams, J., MacKinnon, D.P. 2008. Resampling and distribution of the product methods for testing indirect effects in complex models. Structural equation modeling: a multidisciplinary journal, 15(1), 23-51. https//doi.org/ $10.1080 / 10705510701758166$.

Zemtsov, S. 2020. Institutions, entrepreneurship, and regional development in Russia. Journal of the New Economic Association, 46(2), 168-180. https://10.31737/22212264-2020-46-2-9.

Zhao, H., Seibert, S.E., Hills, G.E. 2005. The Mediating Role of Self-Efficacy in the Development of Entrepreneurial Intentions. Journal of Applied Psychology, 90(6), 1265-1272. https://doi.org/ 10.1037/0021-9010.90.6.1265.

Zhao, X., Lynch, J.G., Chen, Q. 2010. Reconsidering Baron and Kenny: Myths and Truths about Mediation Analysis. Journal of Consumer Research, 37(2), 197206. https://doi.org/ 10.1086/651257. 